\title{
Reason for Direct Part Exempt Marking
}

National Cancer Institute

\section{Source}

National Cancer Institute. Reason for Direct Part Exempt Marking. NCI Thesaurus. Code C101700.

An explanation why a medical device product is exempt from direct part marking. 